УДК 94(477.43)

\title{
Ігор Старенький,
}

кандидат історичних наук, провідний науковий співробітник науково-експозиційного відділу Кам'янеиь-Подільського державного історичного музею-заповідника, науковий співробітник Кам'янеиь-Подільської архітектурно-археологічної експедииї НДЦ «Охоронна археологічна служба України» Інституту археології НАН України

E-mail: starenkiy_igor@ukr.net

\section{Ярина Зайшлюк,}

гід-перекладач Кам'янещь-Подільського державного історичного музею-заповідника

E-mail: yarasem1902@ukr.net

${ }^{1}$ Сецинский, Е.И. (1895). Город Каменеи-Подольский. Историческое описание, Тип. С. В. Кульженко, Киев.

${ }^{2}$ Rolle, J. (1880). Zameczki Podolskie na Kresach Multańskich T. II, Warszawa, $304 \mathrm{~s}$.

${ }^{3}$ Prusiewicz, A.M. (1915). Kamieniec Podolski: szkic historyczny, Leon Idzikowski, Kijow; Warszawa.

${ }^{4}$ Петров, М.Б. (2002). Історична топографія Кам'яния-Подільського кіния XVII-XVIII cm. (Icmopiozpaфiя. Джерела), Абетка-НОВА, Кам'янець-Подільський.

${ }^{5}$ Будзей, О.В. (2005). Вулииями Кам'яния-Подільського, Світ, Львів.

${ }^{6}$ Прокопчук, B.C., Старенький, I.О. (2014).

Топонімічний словник Кам'янияя-Подільського, ПП Зволейко Д. Г., Кам'янець-Подільський.

\section{КОМУНІЗАЦІЯ ТА ДЕКОМУНІЗАЦІЯ ТОПОНІМІВ КАМ'ЯНЦЯ-ПОДІЛЬСЬКОГО}

У статті розглядаються зміни на топонімічній карті Кам'яния-Подільського протягом 20-х років XX - початку XXI cm., які пов'язані $з$ процесом комунізаиії урбанонімів у радянський період та декомунізаиії в період незалежності України, у тому числі за Законом України «Про засудження комуністичного та націонал-соціалістичного (нащистського) тоталітарних режимів та заборону пропаганди їх символіки».

Ключові слова: Кам'янець-Подільський, топонімія, мікротопоніми, урбанонім, перейменування, декомунізація, Закон України.

$\Phi$ ормування топонімії населеного пункту розпочинається 3 його виникненням. Цей процес $є$ складним та безперервним. Часто він залежить від суспільно-політичної ситуації і несе на собі відбитки різних історичних епох, які проходить у своєму розвитку населений пункт. Складним та неоднозначним $\epsilon$ радянський період, який відзначається комунізацією топонімії міст і сіл. У більшості з них ці процеси не вивчені сучасними дослідниками-топонімістами, які досліджують урбаноніми. Занадто заполітизованим, а подекуди й хаотичним, $є$ сучасний процес декомунізації, що вимагає вивчення досвіду наших попередників у цьому питанні.

До топонімії Кам'янця-Подільського зверталися у своїх працях Ю.Й. Сіцінський ${ }^{1}$, Ю. А. Ролле ${ }^{2}$, О. М. Прусевич ${ }^{3}$, М. Б. Петров $^{4}$, О. В. Будзей ${ }^{5}$ В. С. Прокопчук, І. О. Старенький ${ }^{6}$ тощо. Проте дослідники не зосереджували увагу на питаннях комунізації та декомунізації топонімії міста. 
3 приходом радянської влади ситуація на топонімічній карті Кам'янця-Подільського різко змінилася. Нова влада намагалася стерти з історичної пам'яті все, що могло б нагадувати попередню добу, у тому числі шляхом брутального втручання в топонімію міста, насаджування назв, пов'язаних з революційними подіями.

Значні перейменування радянської доби в Кам'янці-Подільському було здійснено 1923 року. Міська рада перейменувала вулиці:

\section{Стара назва}

Петроградська

Коріатовичів

Поштова

Кишинівська

Хрестова

Жандармська

П’ятницька

Резервуарна

Московська

Троїцька

Поліцейська

Соборна

Губернаторський майдан

Дворянська

Старопоштова

Архієрейська

\section{Нова назва}

Петровського

Нероновича

Леніна

Драгоманова

Михайличенка

Іваницького

Бебеля

Примакова

Затонського

Раковського

Урицького

Маркса

Троцького

Лібкнехта

Вутіша

III Інтернаціоналу?
Червоний кордон, 20 берез, с. 2.

${ }^{8}$ Державний архів

Хмельницької області, ф. p-335, оп. 1, спр. 29, арк. 36.

${ }^{9}$ Там само, спр. 63, арк. 102 зв.

${ }^{10}$ Там само, спр. 89, арк. 1.
Невдовзі 10 новим вулицям було дано назву Нова, Пролетарська, Будьонного, Свердлова, Тургенєва, Зінов'єва, Декабристів, Каменєва, Кольцова. 11 вересня 1925 року деякі назви з цього списку було змінено: вулиця Нова отримала ім'я Багінського, Толстого - Склянського, Тургенєва - Ботвина, Кольцова - Фрідмана ${ }^{8}$. Дещо пізніше вулицю Пролетарську перейменовано на Фрунзе.

20 грудня 1927 року рішенням міської ради провулок Торгівельний перейменований на честь єврейського письменника Менделе Мойхер-Сфоріма, який у місті розпочинав свою діяльність9. У списку вулиць на грудень 1927 року вже було близько 20 мікротопонімів, пов'язаних з компартією та ії діячами. Вимальовувалася чітка тенденція радянізації міської топонімії.

15 березня 1928 року рішенням міськради нові вулиці в районі залізничного вокзалу отримали назви Вокзальна, Червоноармійська, Льва Толстого, Рикова ${ }^{10}$.

3 початком репресій почалася нова серія топонімічних змін. У протоколі засідання міськради №14 від 20 грудня 1927 р. зазначено: «Маючи на увазі, що деякі вулиці в м. Кам'янці названі ім'ям Троцького і Раковського, а останні протягом довгого часу проводили антирадянську політику і в сучасний момент остаточно себе скомпрометували перед трудящими Радянської Республіки, дякуючи антирадянським своїм виступам, рахувати за потрібне змінити назву цих вулиць і вулицю Раковського назвати ім'ям т. Дзержинського, площу Троцького назвати Радянською, вулицю Троцького - Радянською» ${ }^{11}$. 
12 Там само, спр. 543, арк. 7071.

13 Там само, оп. 6, спр. 70, арк. 247.

${ }^{14}$ Там само, арк. 246.

15 Там само, оп. 10. спр. 17 , арк. 221-222.

16 Там само, спр. 14, арк. 103104.

17 Там само, спр. 74, арк. 494495.

18 Там само, спр. 154, арк. 65.
9 квітня 1936 р. перейменування зазнали 53 вулиці та провулки, 3 сквери ${ }^{12}$.

5 червня 1947 р. міськрада постановила назвати низку вулиць хутора Дембицького (сучасне селище Смирнова) іменами Короленка, Панфілова, Мічуріна, Лисенка, Ватутіна, Черняхівського, Смирнова ${ }^{13}$. Тоді ж було вирішено: «Запроектованим вулицям кварталу нового житлового будівництва в районі Кам'янець-Подільської МТС (сучасне селище Жовтневе. - Авт.) дати наступні назви: шлях Кам'янець-Подільський-Стара Ушиця вважати продовженням вул. Чкалова. Рівнобіжно вулиці Чкалова - вулиця Гастелло. Середній провулок назвати провулком Чкалова, крайній східний провулок, що межує із землями сільськогосподарської артілі «XX-річчя Жовтня» с. Жовтневе, назвати провулком Матросова» ${ }^{14}$.

Останні перейменування радянської доби припадають на 23 січня 1990 року. Тоді в селищі Жовтневому новим вулицям було дано назви Жовтнева, Інтернаціональна, Поворіна та Вишневий провулок; у Довжку - Бажана, Правди, Шкільна, Радянська, Кушелєва, Сіцінського, Чеботарьова, Бугайченка, Боженка, Пролетарська, Лісова, Подільська та провулок Бажана ${ }^{15}$.

Всього в радянський період було здійснено близько 200 найменувань і перейменувань (42,5\% усіх топонімів та відповідно 57,5\%). Зміни в топонімії міста проводилися за ідеологічними критеріями: топонімічні об'єкти отримували назви, пов'язані 3 революційними подіями, діячами компартії. Українська історія та iï постаті рідко знаходили місце на топонімічній карті міста.

3 незалежністю України розпочався новий етап у формуванні топонімії Кам'янця-Подільського. Ї̈ї основний напрям - відновлення історичних назв.

Перші перейменування проведені міською радою ще 11 вересня 1990 року в умовах функціонування радянської влади. Зміни торкнулися в першу чергу Старого міста - історичного центру Кам'янця-Подільського: 32 топонімічним об'єктам було повернуто їх історичні назви, з'явились вулиці П'ятницька, Тринітарська, Вірменська, Старобульварна тощо. ${ }^{16}$ Цей крок був позитивно оцінений жителями міста.

23 березня 1991 року виконком з метою збереження історико-архітектурної спадщини подільського краю, більш повного відродження історико-архітектурного заповідника знову обговорив питання повернення новій групі географічних об’єктів міста їх історичних назв ${ }^{17}$.

1 червня 1992 року перейменування торкнулося ще 12 топонімічних об'єктів центральної частини міста: площу Леніна назвали майданом Відродження, проспект Леніна - проспектом Грушевського, вулицю Ленінградську - Лесі Українки, Московську - Огієнка, Дзержинського - Данила Галицького, Котовського - Соборною, Паризької комуни - Гунською, Ленінської «Іскри» - Драй-Хмари, 26 бакинських комісарів - Сіцінського, Чкалова - князів Коріатовичів, Жовтневої революції - Північною ${ }^{18}$.

15 липня 1993 року «з метою увічнення імені Клавдія Сафоновича Веліканова, заслуженого лікаря України, учасника Вели- 
${ }^{19}$ Там само, спр. 228, арк. 122.

${ }^{20}$ Там само, спр. 232, арк. 92.

${ }^{21}$ Там само, спр. 233, арк. 50.

22 Там само, спр. 237, арк. 24.

${ }^{23}$ Голос України (2015), 20 трав, (№87(6091), 15-19.

${ }^{24}$ Бутко, С.В., Мужикова, Н.М. (2014). Як перейменувати вулицю. Правові засади перейменування вулицьь, провулків, проспектів, плош, скверів, мостів та інших споруд, розташованих на території населених пунктів: метод. зб., Київ; Чернігів. кої Вітчизняної війни, який протягом майже 40 років (з 1946 по 1985 рік) працював у Кам'янці-Подільському, доклав багато зусиль для оздоровлення населення міста та району», вулицю Калініна було перейменовано на вулицю Веліканова ${ }^{19}$.

13 серпня 1993 року міськрада вулицю Крупської розділила на дві частини й назвала іменами Володимира Гагенмейстра та маршала В. К. Харченка ${ }^{20}$.

16 вересня 1993 року «у зв’ язку з тим, що вулиці міста носять імена Постишева та Петровського, які були одними з організаторів голодомору в Україні 1932-1933 років, та з метою увічнення імен людей, життя і діяльність яких пов'язані з історією м. Кам'янця-Подільського», виконком прийняв рішення перейменувати вулицю Постишева на Івана Крип'якевича, Ульянової - на Ісайї Кам'янчанина, а вулиці Петровського повернути стару назву Панівецька ${ }^{21}$.

4 листопада 1993 року новим вулицям у мікрорайоні Жовтневий надали тимчасові назви - Проектна-1, Проектна-2, Проектна-3 та провулок Проектний. Цього ж дня рішенням за №1358 три вулиці перейменували на честь міст-партнерів: вулицю 7-го листопада - на Каліську, Червоного козацтва - на Укмергеську, Примакова - на Мічурінську 22 .

3 прийняттям 9 квітня 2015 року, підписанням та опублікуванням пакету законів про декомунізацію 20 травня того ж року, в тому числі Закону України «Про засудження комуністичного та націонал-соціалістичного (нацистського) тоталітарних режимів та заборону пропаганди їх символіки» ${ }^{23}$, у населених пунктах нашої держави розпочинається процес декомунізації топонімії міст та сіл.

Практично єдиною на сьогодні науковою працею, присвяченою питанням перейменування вулиць, є методичний збірник «Як перейменувати вулицю» (2014), який являє собою переважно зібрання правових та нормативних документів, необхідних у процесі перейменування урбанонімів ${ }^{24}$.

У Кам'янці-Подільському ситуація з декомунізацію урбанонімів виявилася нескладною, оскільки більшості історичних вулиць було повернуто автентичні назви 1990 року, а деяким об'єктам $\mathrm{XX}$ ст. надано імена видатних українських діячів, життя та доля яких пов'язана з містом. Водночас залишалася частина урбанонімів, які несли ідеологічне навантаження комуністичного режиму. До переліку увійшли 44 вулиці. Частина 3 них названа іменами, які входять до «Списку осіб, які підпадають під Закон про декомінузацію», підготовлений Інститутом національної пам'яті, зокрема В. Чапаєва, Й. Якіра, М. Щорса, Г. Жукова, І. Кулика, Я. Фабріціуca, А. Гайдара тощо.

Реєстр вулиць, що підлягають перейменуванню, було затверджено рішенням сесії Кам'янець-Подільської міської ради ще 21 квітня цього року. Пропонувалося перейменувати 15 вулиць: В. Вутіша, Г. Жукова, В. Затонського, М. Козицького, М. Криленка, В. Куйбишева, О. Пархоменка, Я. Фабриціуса, М. Фрунзе, Д. Фурманова, С. Ценського, В. Чапаєва, Червоноармійська, Шмідта і Й. Якіра та 9 провулків. Тоді ж топонімічній комісії доручили про- 
${ }^{25}$ Будзей, О.В. (2016)

«Декомузація: перші шість. Далі буде...», Подолянин, 16 верес. (№38(1361)), с. 3; Шуханова, Т.М. (2016), «За землю воювали і вулиці перейменували», КлюЧ, 16 верес. (№38(240)), с. 1-2. вести вивчення громадської думки мешканців відповідних вулиць та провулків стосовно їх перейменування. У додатковий перелік вулиць, крім основного, увійшло ще чотирнадцять. Наприклад, вулиці Першотравнева, О. Суворова, 30 років Перемоги, С. Васильєва, І. Папаніна, М. Ватутіна тощо. Загалом в основному та додатковому списку 44 вулиці підлягають перейменуванню.

Проте процес декомунізації урбанонімів Кам'янця-Подільського майже півроку стояв на місці. Не в останню чергу цей процес гальмувала громадськість, яка виступала проти перейменування у зв'язку з необхідністю внесення змін у документи. Не надто переймалися цим і депутати міської ради, а топонімічна комісія при міськвиконкомі - лише дорадчий громадський орган, який не має впливу на прийняття жодних рішень. Лише 14 вересня на XVII сесії Кам'янець-Подільської міської ради було прийнято рішення про перейменування частини вулиць зі згаданого списку, а саме шести ${ }^{25}$. Відтак, вулиця Червоноармійська тепер стала вулицею Героїв Небесної сотні, а вулиця Жукова - Миколи Гордійчука. Остання названа іменем кам'янчанина Миколи Миколайовича Гордійчука (26.05.1986 - 22.07.2015) - українського співака, шоумена, молодшого сержант міліції, міліціонера батальйону патрульної служби міліції особливого призначення «Гарпун» ГУМВС України в Київській області, кавалера ордена «За мужність» III ступеня (посмертно), який отримав смертельне поранення поблизу блокпосту «Шахта», між містами Авдіївка та Ясинувата (Донецька область). Провулок М. Будьонного перейменували на честь Миколи Флерка (22.08.1978 - 28.02.2015) - почесного громадянина Кам'янця-Подільського, бійця Добровольчого Українського корпусу, який загинув у с. Піски (Ясинуватський район) під Донецьком у результаті мінометного обстрілу знімальної групи російськими бойовиками. 28 липня 2015 року нагороджений нагрудним знаком «За оборону Донецького аеропорту» (посмертно). Провулок М. Калініна отримав ім'я Романа Наглюка (14.03.1986 - 4.08.2014) - капітана ЗСУ, командира танкового батальйону, який загинув біля с. Волнухине Лутугинського району на Луганщині під час нічного обстрілу 3 РСЗВ «Град». Нагороджений орденом Богдана Хмельницького III ступеня (посмертно). Провулок Я. Фабриціуса перейменували на честь Віталія Васільцова (16.11.1977 - 18.02.2014) - активіста Революції Гідності, майстра декоративного садівництва, який загинув у Києві на Великій Житомирській вулиці від прицільного пострілу з автоматичної зброї. Нагороджений званням Героя України з удостоєнням ордена «Золота Зірка». Провулок В. Чапаєва отримав ім'я Сергія Бондарчука (9.09.1961 - 20.02.2014) - героя Небесної сотні, громадсько-політичного діяча, активного учасника Революції Гідності, вчителя фізики Старокостянтинівської гімназії, який у 1978-1983 рр. навчався на фізико-математичному факультеті Кам'янець-Подільського педагогічного інституту (нині - Кам'янець-Подільський національний університет імені Івана Огієнка).

Як бачимо, процес декомунізації поєднався 3 увічненням пам'яті тих, хто загинув на Майдані чи в ході російсько-української війни на Сході України. Окрім перейменованих вулиць та провулків, під декомунізації підпадає ще 38 урбанонімів. 


\section{References}

Derzhavnyi arkhiv Khmelnytskoi oblasti, f. r-335, d. 1, c. 29, 53 p. Derzhavnyi arkhiv Khmelnytskoi oblasti, f. r-335, d. 1, c. 63, 274 p. Derzhavnyi arkhiv Khmelnytskoi oblasti, f. r-335, d. 1, c. 89, 37 p. Derzhavnyi arkhiv Khmelnytskoi oblasti, f. r-335, d. 1, c. 543, 134 p. Derzhavnyi arkhiv Khmelnytskoi oblasti, f. r-335, d. 6, c. 70, 251 p. Derzhavnyi arkhiv Khmelnytskoi oblasti, f. r-335, d. 10, c. 14, 188 p. Derzhavnyi arkhiv Khmelnytskoi oblasti, f. r-335, d. 10, c. 17, 312 p. Derzhavnyi arkhiv Khmelnytskoi oblasti, f. r-335, d. 10, c. 74, 522 p. Derzhavnyi arkhiv Khmelnytskoi oblasti, f. r-335, d. 10, c. 154, 66 p. Derzhavnyi arkhiv Khmelnytskoi oblasti, f. r-335, d. 10, c. 228, 233 p. Derzhavnyi arkhiv Khmelnytskoi oblasti, f. r-335, d. 10, c. 232, 122 p. Derzhavnyi arkhiv Khmelnytskoi oblasti, f. r-335, d. 10, c. 233, 322 p. Derzhavnyi arkhiv Khmelnytskoi oblasti, f. r-335, d. 10, c. 237, 81 p. $272 \mathrm{p}$.

Budzey, O.V. (2005). Vulytsiamy Kamiantsia-Podilskogo, Svit, Lviv,

Budzey, O.V. (2016). «Dekomunizatsiia: pershykh shist. Dali bude...», Podolyanyn, Sept. 16. (№38 (1361)), p. 3.

Butko, S.V. Muzhikov, N.M. (2014). Yak pereimenuvaty vulytsiu. Pravovi zasady pereimenuvannia vulyts, provulkiv, prospektiv, ploshch, parkiv, skveriv, mostiv ta inshykh sporud, roztashovanykh na terytorii naselenykh punktiv: metodychnyi zbirnyk, Kyiv; Chernihiv, $122 \mathrm{p}$.

Golos Ukrainy, (2015). 20 May (№87 (6091)), p. 15-19.

«Novi nazvy vulyts», (1923). Tchervoniy cordon, March 20, p. 2.

Petrov, M.B. (2002), Istorychna topografiia Kamiantsia-Podilskogo kintsia XVII - XVIII stolittia. (Istoriografiia. Dzherela), Abetka-NOVA, Kamyanets'-Podil's'ky, 384 p.

Prokopchuk, V.S., Starenkiy, I.O. (2014). Toponimichnyi slovnyk Kamiantsia-Podilskogo, PP Zvoleyko D.G., Kamyanets'-Podil's'ky, 192 p.

Prusiewicz, A.M. (1915). Kamieniec Podolski. Szkic historyczny, Leon Idzikowski, Kiev; Warszawa, $128 \mathrm{s.}$

Rolle, J. (1880). Zameczki podolskie na kresach multanskich T. II, Warszawa, $304 \mathrm{~s}$.

Setsynskiy, E.Y. (1895). Gorod Kamenets-Podolskyi. Ystorycheskoe opysanye, The type. S.V. Kulzhenko, Kiev, 247 p.

Shuhanova, T.N. (2016). «Za zemliu voiuvaly i vulytsi pereimenovuvaly», Klyutch, Sept. 16. (№38 (240)), p. 1-2.

\section{Ярина Зайшлюк, Игорь Старенький \\ КОММУНИЗАЦИЯ И ДЕКОММУНИЗАЦИЯ ТОПОНИМОВ КАМЕНЦА-ПОДОЛЬСКОГО}

В статье рассматриваются изменения на топонимической карте Каменеи-Подольского в течение 20-х годов XX - начала XXI в., связанные с процессом коммунизации урбанонимов в советский период и декоммунизачии в период независимости Украины, в том числе связанный с Законом Украина «Об осуждении коммунистического и начионал-сочиалистического (нацистского) тоталитарных режимов и запрет пропаганды их символики».

Ключевые слова: Каменец-Подольский, топонимика, микротопонимы, урбаноним, переименование, декоммунизация, Закон Украины. 


\section{Jaryna Zajshljuk, Igor Staren'nyj}

\section{COMMUNIZATION AND DE-COMMUNIZATION OF TOPON- YMY IN KAMYANETS'-PODIL'S'KY}

The article tells about change on toponymy map in Kamyanets'-Podil's'ky for 20 year XX-begin XXI century, what is consist of communization's urbanonimiv in Soviet period. Within 20 years, most microtoponyms that do not fit into the ideological system of the Communist Party were renamed - it was given the name of party and military leaders of the USSR, the ideologists of the communist movement. In 30 years of these objects were renamed due to the unprecedented scale repressive movement and different kinds of executions of Soviet leaders. After the war Communization toponymy held mainly by the new street names, instead of renaming existing ones. Since the beginning of the collapse of the Soviet Union and the loss of dominance of the Communist Party ideology, starts reverse process - decommunisation. Primarily old name was returned to the historic streets of Kamyanets'-Podil's 'ky in 1990 over 1992-1995. De-communization held by renaming streets of the new city, which bore the names of communist leaders. New round of decommunisation associated with the Revolution of dignity and the Law of Ukraine "On the condemnation of Communist and National Socialist (Nazi) totalitarian propagation and ban their symbols.» During this period, toponymic objects included in the list of those subject decommunisation given new names. If the situation Kamyanets'-Podil's'ky, streets and lanes provided the names of the dead patriots during the Revolution of dignity and Russian-Ukrainian war in Eastern Ukraine.

Key words: Kamyanets'-Podil's 'ky, toponymy, microtoponym, urbanonimiv, renamed, decommunisation, the Law of Ukraine. 